\title{
The Establishment of an Aerospace Industry Center in the Trans-Baikal Territory as a Link Between Siberia and the Far East
}

\author{
Alexey V. Drobotushenko \\ and Yakov A. Sukhodolov* \\ Ministry for International Cooperation and \\ Foreign Economic Relations of Zabaykalsky Region \\ 37 Anokhina Str., Chita, 672010, Russia
}

Received 26.05.2017, received in revised form 07.11.2017, accepted 14.11.2017

The article is devoted to the establishment of a new center of the Russian aerospace industry in Chita with the participation of Roskosmos and Rostekh state corporations. It is noted that the deterioration of the social and economic situation of the Trans-Baikal Territory is caused by the liquidation of the Trans-Baikal Military District. The authors make conclusion that the establishment of an aerospace industry center focused on the production of high-tech products in demand in Russia and Asia-Pacific countries will enable the use of the engineering and scientific potential of Siberia and the Far East, will contribute to the economic, industrial and intellectual development of the Trans-Baikal Territory, and will also have a positive impact on the economy of the regions of the Siberian Federal District and the Far Eastern Federal District.

Keywords: Siberian Federal District, Far Eastern Federal District, Trans-Baikal Territory, Krasnoyarsk Territory, aerospace industry, machine building, Vostochny Cosmodrome.

DOI: 10.17516/1997-1370-0164.

Research area: economics.

Currently, the Trans-Baikal Territory is in a difficult socio-economic situation. The reasons for the deterioration of the social and economic situation of the region over the past three decades are many, but among them there is one that very few people pay attention to. In 1998, the TransBaikal Military District ceased to exist with the location of its administration in Chita (O voennoadministrativnom delenii...). Together with the Trans-Baikal Military District, the region lost federal funding, which went through the Russian Ministry of Defense. The traces of the stay of the administration of the Trans-Baikal military district are still preserved in Chita, but there are no previous funds from the country's defense budget to the Trans-Baikal Territory.

At the same time, the region lost the regionforming basis of financing and development prospects. With the elimination of the TransBaikal Military District, tens of thousands of

(c) Siberian Federal University. All rights reserved

* Corresponding author E-mail address: drobotushenko@ves.e-zab.ru; yakov.suhodolov@gmail.com 
highly qualified officers and technical workers, mostly those with higher education, left. Their wives, who constituted the backbone of education, culture and health of Transbaikalia, as well as their children, the future of the region, left together with them.

We must not forget about the sad experience with Ukraine. Being stuffed with the investment and territories by the union center, the western edge of the country has disappeared. There are fears that the same threat now hangs over the eastern edge of Russia, which has received significant budgetary infusions in recent years and which neighbors to such economically developed countries as China, the US, and Japan. To prevent such a course of events, it is required to firmly link the Far East with Siberia and all of Russia, but above all with the Trans-Baikal Territory.

The establishment of an aerospace industry center, which belongs to the most technologically advanced branches of machine building with a high degree of cooperation and concentration of production, and also plays a leading role in ensuring Russia's national security can be one of the promising areas of social and economic development of the Trans-Baikal Territory (Timofeichev, 2013).

The project to create an aerospace industry center in the Trans-Baikal Territory is included in the "Comprehensive Plan for the Social and Economic Development of the Trans-Baikal Territory until 2030", which is currently being developed in cooperation with interested federal executive bodies of the Russian Federation (in accordance with the instruction of the President of Russia V.V. Putin Pr-3082 dated October 31, 2016).

The government of the Trans-Baikal Territory supports the idea of creating a new center of the Russian aerospace industry in the region, since the deployment of new enterprises in the machine-building complex, including the defense industry enterprises, will positively affect the social and economic development of the Trans-Baikal Territory and enhance the country's defense capability in the Far East.

In our opinion, the strongest linkage of the Far East to Trans-Baikal is the entry of the Trans-Baikal Territory into an aerospace cluster forming around the Vostochny Cosmodrome located in the neighboring Amur Region. The enterprises of aerospace mechanical engineering and instrument making complementing it can be located in the Trans-Baikal Territory and have a number of advantages in comparison with aerospace centers in the European part of Russia, in particular, in the Samara region:

Firstly, the center of the aerospace industry in Transbaikal will have a smaller shoulder of territorial remoteness from the Vostochny Cosmodrome.

Secondly, it will play the role of a "backup" aerospace industry in Samara, which is very important for ensuring state security (the aerospace cluster in the Samara region is territorially very compact, which, along with economic advantages, makes it vulnerable in the event of military and terrorist attacks).

Thirdly, it will become a high-tech link between the Far Eastern subjects of the Russian Federation and the subjects of the Russian Federation that are part of the Baikal region (including the Irkutsk Region and the Republic of Buryatia with aircraft manufacturing enterprises operating in their territories), and the Krasnoyarsk Territory, where missile production is concentrated and the personnel training for the aerospace industry takes place.

The machine-building complex of the aerospace industry of the Krasnoyarsk Territory can advance in the Transbaikal, creating here several additional enterprises for the production 
of satellite antennas, cable products for missiles and aircraft, navigation equipment, etc.

We look forward to active expert support from the Krasnoyarsk regional branch of the Russian Union of Machine Builders and scientists from Reshetnev Siberian State Aerospace University.

It is very important to attract such state corporations as Roskosmos and Rostekh to creating the aerospace complex enterprises in Transbaikal. Especially it concerns Rostekh, which includes Almaz-Antei and Radioelectronic Technologies group companies that are able to become investors in the region. For example, Almaz-Antei in a short time built a machinebuilding plant in Kirov (investments of more than 20.0 billion rubles, including 13.0 billion rubles, own funds of Almaz-Antei) (Aktsionernoe obshchestvo...).

The launch of high-tech products, including those required for the implementation of federal targeted programs (such as The Development of the Defense Industry and the Federal Space Program), the orders of Rostekh and Roskosmos state corporations, the needs of the Vostochny Cosmodrome and the enterprises of the aviation industry (aircraft plants in Irkutsk, Ulan-Ude and Komsomolsk-on-Amur) that are available in the Baikal region and in the Far East of Russia will make it possible to effectively use the engineering and scientific potential, economic, industrial and intellectual development of the region, as well as open new opportunities for the development of agriculture, food industry and services, including the sanatorium and resort complex.

The establishment of an aerospace industry center oriented, inter alia, to export production, will promote economic and technological cooperation of Russia with China, India, Malaysia and other countries of the Asia-Pacific region, and will also provide the company with long-term orders (Prokopenkova, 2012).
For a detailed study of the issues related to the establishment of a new center of the Russian aerospace industry on the territory of the Trans-Baikal Territory (such as determining the list of products, personnel, site selection, etc.), coordinated work is required at the level of the Government of the Russian Federation, involving representatives of the Ministry of Industry and Trade of Russia, the Ministry of Economic Development of Russia, Rostekh and Roskosmos state corporations, the Vostochny Cosmodrome, aviation plants in Irkutsk, Ulan-Ude and Komsomolsk-on-A Mura, Krasnoyarsk regional department of the Union of Machine Builders of Russia, Reshetnev Siberian State Aerospace University, as well as the Government of the Trans-Baikal Territory.

The issue of staffing the cluster with highly qualified specialists can be solved by Siberian universities that train personnel for high-tech industries. Suffice it to call Reshetnev Siberian Aerospace University and Tomsk University of Control Systems and Radioelectronics. Besides, Trans-Baikal State University and Irkutsk National Research Technical University could refocus on the training of the demanded engineering personnel for the needs of the new aerospace center.

At the same time, there is a hope that experts in the aerospace industry of Ukraine can come to Transbaikal. They are a ready human capital, to attract which you need to build a modern comfortable city-satellite next to Chita, which will have a positive impact on the demographic situation in the Trans-Baikal Territory.

The establishment of an aerospace industry center in the Trans-Baikal Territory will:

- become a logical conclusion of the chain of the aviation industry enterprises that are already available in the east of Russia; 
- create a network of associated industries both in the region itself and in neighboring constituent entities of the Russian Federation in the Siberian Federal District and the Far Eastern Federal District;

- accelerate the growth of the share of high-tech products in the total volume of industrial production in the east of Russia;
- ensure economic and technological cooperation of Russia with China and other the APR countries;

- allow using the engineering and scientific potential of our compatriots from Ukraine and other CIS countries;

- enable the rapid economic, production and intellectual development of the Trans-Baikal Territory.

\title{
References
}

O voenno-administrativnom delenii Rossiiskoi Federatsii [Elektronnyi resurs]. Ukaz Prezidenta Rossiiskoi Federatsii ot 27 iiulia 1998 goda № 900 - Dostup iz SPS «Konsul'tantPlius» [On the military-administrative division of the Russian Federation. Decree of the President of the Russian Federation No. 900 of July 27, 1998. Accessed at ConsultantPlus legal-reference system].

Timofeichev, A. (2013). Kosmicheskuiu promyshlennost' Rossii sdvigaiut na Vostok [The Russian space industry is moving east. Created on October 24, 2013], In Russkaia sluzhba Bi-Bi-Si [BBC Russian service]. Available at: www.bbc.com/russian/russia/2013/10/131024_rogozin_far_east_ space_industry (Accessed April 4, 2017).

Aktsionernoe obshchestvo "Kirovskoe mashinostroitel'noe predpriiatie»: of its. sait. [Joint-stock company "Kirov machine-building enterprise": official website]. Available at: www.kmp43.ru

Prokopenkova, I.O. (2012). Sovremennye tendentsii razvitiia mezhdunarodnoi kooperatsii v mirovoi aerokosmicheskoi promyshlennosti: faktor Kitaia i Indii [Modern trends in the development of international cooperation in the global aerospace industry: the factor of China and India], In I.O. Prokopenkova. Problemy natsional'noi strategii [I.O. Prokopenkova. Problems of the national strategy], 2 (11), 122-137.

\section{Создание в Забайкальском крае центра аэрокосмической промышленности как связующего звена Сибири и Дальнего Востока}

\author{
А.В. Дроботушенко, Я.А. Суходолов \\ Министерство международного сотрудничества \\ и внешнеэкономических связей Забайкальского края \\ Россия, 672010, Чита, ул. Анохина, 37
}

$\overline{\text { В статье рассматривается вопрос о создании нового иентра аэрокосмической промышлен- }}$ ности России в г. Чите при участии государственных корпораций «Роскосмос» и «Ростех». Отмечается, что ухудшение социильно-экономического положения Забайкальского края вызвано ликвидацией Забайкальского военного округа. Сделан вывод о том, что создание иентра аэрокосмической промышленности, ориентированного на выпуск востребованной в России 
и странах АТР высокотехнологичной продукичи, позволит задействовать инженерно-научньй потенциал Сибири и Дальнего Востока, будет способствовать экономическому, производственному и интеллектуальному развитию Забайкальского края, а также окажет положительное влияние на экономику регионов СФО и ДФО.

Ключевые слова: СФО, ДФО, Забайкальский край, Красноярский край, аэрокосмическая промылиленность, машиностроение, космодром «Восточный».

Научная специиальность: 08.00.00 - экономические науки. 